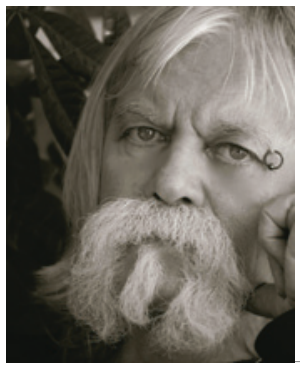

Yngve Hammerlin

Dr.philos., forfatter og forsker ved Kriminalomsorgens utdanningssenter Foto: Doris Bakken

\title{
Når fysisk og psykisk vold blir en reduksjonisme
}

\author{
Jeg er vokst opp i en ekstremt \\ voldelig og totalitær familie, \\ og holder mange forelesninger \\ for helsepersonell om det.
}

Jeg holder også forelesninger om vold i fengslene og om boken Voldens ansikter (2014). Med boken I fars vold (2000) var jeg kommet til et analytisk knutepunkt som fikk teoretiske konsekvenser - for hvordan ble volden forstått og formidlet av mange fagfolk? Fortvilende forenklet. Mitt innenfraperspektiv som offer og voldsforsker ble derfor et faglig blikkskifte.

For det første utviklet jeg begrepet «totalitær familie» for å kunne forstå det som skjer i en familie der krenkelser, undertrykkelse, makt- og voldsbruk er et konstant, kompakt og strukturelt trekk ved familielivet. Krenkelses- og hersketeknikkene er innvevd i hverdagslivet og levemåten. En slik familie er et lukket system som skiller seg fra andre voldsplagede familier der voldsbruken kan være like brutal, men mer episodisk. Min «far» produserte et makttrykk som var ubønnhørlig, fortettet og kompakt et hverdagens terrorregime var det.

For det andre ble utfordringen å utvikle begreper og et analyseverktøy som mer presist og finstemt avdekket det komplekse og mangfoldige makt- og voldsbildet som vi var ofre for. Jeg ville blottlegge brutaliteten og de mer indirekte og subtile volds- og maktformene samt studere det indre forholdet mellom hverdagens undertrykkelse, hersketeknikkene, maktbruken og volden. Det virket som om en del fagpersoner presset analysene inn en teoretisk og begrepsmessig matrise som var gitt på forhånd. Flere opererte nesten bare med fysisk og psykisk vold.

Slik ble det totale makt- og voldsbildet fliset opp og fragmentert. Ved å overfokusere på enkelte voldsformer mister man blikket for andre. Min erfaring tilsa at man måtte studere undertrykkelsen i lys av langt flere voldsformer som her i Tidsskriftet blir lapidarisk presentert som analysekomponenter.

Fysisk vold delte jeg i to: legemlig vold og materiell vold i form av ødeleggelse av ting og gjenstander i den hensikt å plage, krenke eller svekke funksjoner.

Psykisk vold er et grumsete begrep preget av psykologisme («alt» blir redusert til psykologiske forklaringer) - dermed inkluderer det mye det ikke kan dekke. I en begrepsdiskusjon med danske psykologer og filosofer var tilbakemeldingen: Psykisk vold er et utflytende begrep og bør forkastes hvis man ikke tar det til rensing. Så gjort: Psykisk vold må brukes mer distinkt om vold rettet mot den psykiske helsen for å skape psykisk lidelse.

Det må avgrenses fra sosial vold, som bedre dekker former for sosial undertrykkelse, sosial krenkelse, sosial sortering, sosial isolering og ekskludering, sosial diskvalifisering, usynliggjøring, latterliggjøring, kvinneforakt, rasisme osv. Å skape fremmedgjørende avstand til offeret ved å hesliggjøre det er en annen form for sosial vold (estetikkens vold). Sosial vold fortsetter også utenfor hjemmet - bl.a. i nabolaget og skolen. Stor blir den sosiale tapslisten, og den akkumuleres.

Mens verbal og ikke-verbal vold er uttrykk for symbolsk vold, assosieres også visse tegn og gjenstander med vold. Støy, kjefting, utskjelling, gråt og krangel fyller rommet, mens taushetens vold erobrer og gjenstanders vold gjør en kvalm.

Sentrale sosiologiske og sosialfilosofiske begreper blir ustanselig borte i en del analyser, skjønt de representerer selve essensen for å kunne forstå det undertrykte og krenkede livet. Det gjelder både strukturell og systemisk vold - altså de repressive foranstaltningene som er bygd inn hverdagslivet for å sikre maktgrunnlaget, underkastelsen og disiplineringen.

Voldsbruken omfatter også idégrunnlaget for overgrepene og de påvirkningsteknikkene «far» brukte for å erobre vår tankeverden med sine «sannheter», sitt menneskesyn og sine verdipreferanser. Det var en åndelig voldtekt (begrepsfestet som ideologisk vold).

Kort og godt: Makt- og voldsmangfoldet må synliggjøres. En voldshendelse består av flere voldsformer som får ulik betydning og mening i ulike situasjoner. Hendelsene, det inneklemte livet og undertrykkelsen smerter, det er ikke bare enkelte voldsformer som gjør vondt. Min «far» anerkjente ikke vår integritet, han maltrakterte den ved at han tok livskvaliteten fra oss.

Det hevdes at barn i voldsfamilier er «vitner til vold». Bare det? Hvor ofte var ikke vi barna mål for volden? Hvor ofte hang vi ikke i beina og armene hans for å hindre ham i å utføre råskapen mot mor? Barn i voldelige familier er i volden - lever i den. I dette familietyranniet, i denne hverdagens lidelsesproduksjon er volden eksistensiell og må studeres ontologisk, ideologisk, relasjonelt og strukturelt - den knuger, smerter, ødelegger, men skaper også motmakt og avsky for vold.

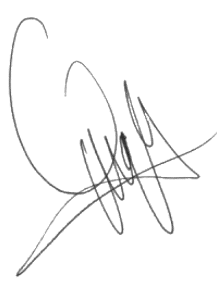

